\title{
Orgya antiqua (Linnaeus) (Lepidoptera: Lymantriidae): an occasional pest on Pelargonium
}

\author{
G. Viggiani \\ Laboratorio di Lotta biologica, Dipartimento di Agraria, Università degli Studi di Napoli \\ Federico II, Italy
}

\begin{abstract}
The larval development of Orgya antiqua on Pelargonium has been reported for the first time.
\end{abstract}

\section{Short paper}

In July 2014 plants of Pelargonium located in Rivello (Potenza), South Italy, Basilicata, in a house at the border of a woody land with Castanea sativa, Quercus spp. and many other broadleaved trees and shrubs, resulted damaged (Figure 1). Their leaves were progressively eroded by caterpillars identified as belonging to the vapourer Orgya antiqua (Linnaeus). Most of the damage was caused by the last instar larvae.

Some of these caterpillars were collected, kept in a box and fed with Pelargonium leaves. They completed their development and pupated in a transparent web cocoon. The adults emerged around mid August. During July-August the species developed one generation, probably the second of the year. The recorded infestation of Pelargonium was most likely caused by young caterpillars passively transported by wind.

O. antiqua is a sexual dimorphic species; the female (Figure 2A) is light grey, covered with greyish white scales and apterous; the male

\footnotetext{
Correspondence: Gennaro Viggiani, Laboratorio di Lotta biologica, Dipartimento di Agraria, Università degli Studi di Napoli Federico II, via Università 133, 80055 Portici (NA), Italy.

Tel.: +39.081.2539003 - Fax: +39.081.7755872

E-mail: genviggi@unina.it

Key words: Geraniums; vapourer; Italy.

Received for publication: 12 September 2014.

Revision received: 23 December 2014.

Accepted for publication: 16 January 2015.

(OCopyright G. Viggiani, 2015

Licensee PAGEPress, Italy

Journal of Entomological and Acarological Research 2015; 47:4705

doi:10.4081/jear.2015.4705

This article is distributed under the terms of the Creative Commons Attribution Noncommercial License (by-nc 3.0) which permits any noncommercial use, distribution, and reproduction in any medium, provided the original author(s) and source are credited.
}

(Figure 2B) has comb-like antennae, fore wings rusty-brown, with white tornal spot in lower part at external margin (wingspan to 30 $\mathrm{mm}$ ). The eggs are greyish (Figure 2C) with a brown micropylar area. The full grown larva (Figure 2D) is grey, with reddish lateral and dorsal spots, tufts of long blackish setae on each side of the prothorax directed forward and two on the eighth abdominal segment in the opposite direction; four yellow, dense tufts of setae are present on the urotergites 1-4; tufts of setae are present at the sides of third and, sometime, second urite.

O. antiqua is widely distributed in Western Europe, the original area, and in many other countries of the Palaearctic and Nearctic regions (Carter, 2004). The number of generations developed in a year varies from 1 to 4 (Tremblay, 1986; Wagner, 2005). The polyphagous caterpillars are able to damage fruit and landscape cultures, such as apple, pear, cherry, bird cherry, roses, mountain ash etc., and also forest trees, preferring willow, poplar, birch, larch. They also cause damage to currant, wild growing rosaceous, maple, linden, cowberry, and bilberry. Insignificant damage is reported on clover, soya, castor oil plant and other herbaceous plants (Carter, 1984; Tremblay, 1986; Porter, 1997; Pollini, 1998). No records have been found in literature concerning Pelargonium spp.

A female lays 100-500 eggs in a batch frequently on the surface of the own pupa cocoon. The larval feeding period lasts 25-55 days for each generation, depending on the environment. In the geographic areas where the species develops four generation a year the young caterpillars emerge from the overwintering eggs in April-May, and their development is completed in June. The subsequent generations, partially overlapping, take place respectively around July, August and October (Tremblay, 1986).

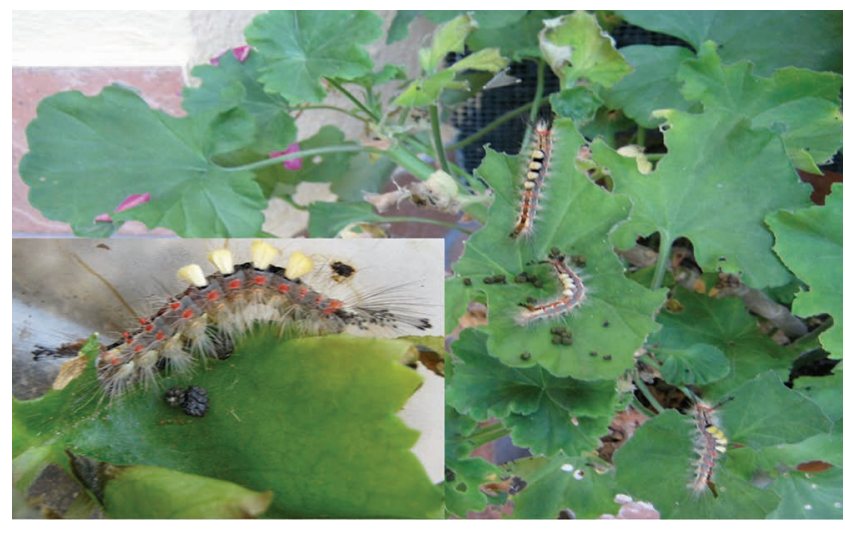

Figure 1. Pelargonium infested by caterpillars of Orgya antiqua. 


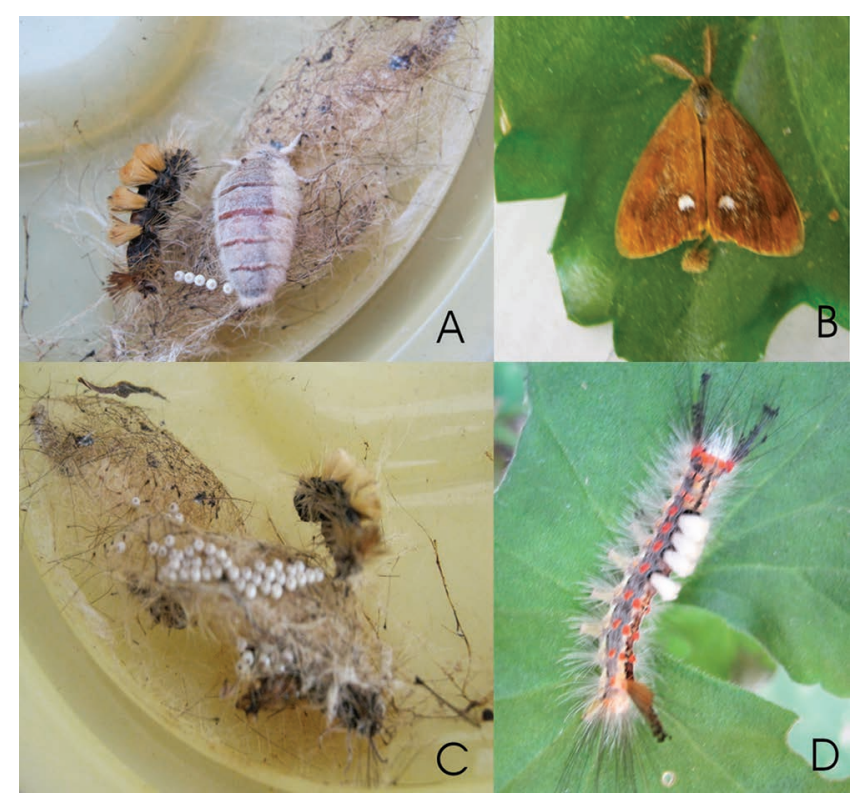

Figure 2. Orgya antiqua: A. female; B, male; C, egg batch; D, larva.
Control measures, if needed, include biological control with formulations of Bacillus thuringiensis applied when the very young caterpillars appear. It is suggested to avoid the use of synthetic insecticides in household environment.

\section{References}

CARTER D.J., 1984 - Pest Lepidoptera of Europe with special reference to British Isles. - Dr W. Junk Publishers, Dordrecht: 431 pp.

CARTER N.E., 2004 - Status of forest pests in New Brunswick in 2003. Department of Natural Resources, Fredericton, New Brunswick: 7-8.

POLLINI A., 1998 - Manuale di entomologia applicata. - Edagricole, Bologna: $1462 \mathrm{pp.}$

PORTER J., 1997 - The colour identification guide to caterpillars of the British Isles. - Viking, London: 275 pp.

TREMBLAY E., 1986 - Entomologia applicata. - Editore Liguori, Napoli: $381 \mathrm{pp}$.

WAGNER D.M., 2005 - Caterpillars of eastern North America. Princeton University Press: 512 pp. 